\title{
Çağdaş Sanatta Yeni Bir Atölye Modeli Olarak Saha Çalışması
}

\section{Özet}

Sanatın kendine özgü doğasının özne, nesne, teknik, mekan, kurum, tekrar, beğeni, estetik vb. dinamiklerinden biri de kuskusuz "atölye"dir. Atölyenin 13.yy'dan günümüze, sanatçıların üretim sürecinde hem maddi, hem de manevi değeri yüksek bir yere sahip olduğu söylenebilir. Zamanın şartlarına göre kendini sürekli dönüştüren, yenileyen ve günümüze kadar uzanan bir olgu olan atölyenin izlerini yansıtmayı hedefleyen bu yazı, aynı zamanda atölyeye alternatif hamleler olarak da okunabilecek "saha çalışması" nın da hem antropolojik boyutlarıı, hem de tarihsel pozisyonunu irdelemeyi hedeflemektedir.

Bu bağlamda hem atölyenin serüvenini, hem de "saha çalıșması" "nı olası koșullarını ve yöntemlerini tartışmaya açarak alternatif üretme metotlarını inceleyebilir, hem de günümüzde sanatçıların tercih ettikleri yeni alan ve anlam arayışlarını bu metotlar üzerinden değerlendirebiliriz.

Anahtar Kelimeler: Atölye, Saha Çalışması, Sanat, Antropoloji, Yöntem

\section{FIELD STUDY AS A NEW FORM OF STUDIO IN CONTEMPORARY ART}

\section{Abstract}

The "Studio" is undoubtedly one of the subject, object, technique, space, institution, repetition, appreciation, aesthetics, etc. dynamics of the specific nature of art. It could be said that the studio has been enjoying a high level of both material and spiritual value in the production process of artists since the 13th century until today. This article aims to reflect the traces of studio, which is a phenomenon that has been transforming and renewing itself continuously according to conditions a phenomenon that has been transforming and renewing itself continuously according to conditions
of the time and surviving until today, as well as to analyze both the anthropological dimensions and historical position of the "field study," which could also be read as alternative movements to the studio.

In this context, we can examine both the adventure of the studio and alternative production methods by discussing possible conditions and methods of the "fieldstudy" and we can also appreciate the search for new space and meanings that artists choose today.

Keywords: Studio, Field study, Art, Anthropology, Method 


\section{Çağdaş Sanatta Yeni Bir Atölye Modeli Olarak Saha Çalışması}

Atölye; hem zanaatta, hem de sanatta Orta Çăg'dan bu yana kullanılan, zaman içerisinde farklı pozisyonlar alan önemli bir olgudur. Amerika'lı Sosyoloji Profesörü Richard Sennett; "Atölye zanaatkarın yuvasıdır." (Sennett,2009: 75) der ve ekler;

Ortaçağlarda zanaatkarlar, çalışıkları yerlerde uyurlar, yerler, içerler ve çocuklarını yetiştirirlerdi. Atölye aileler için bir yuva olması yanı sıra küçük mekanlardı, her birinde en fazla on, on bes kişi bulunurdu; Ortaçağ atölyesinin yüzlerce ya da binlerce insan çalıştıran modern fabrikalarla hiçbir benzerliği bulunmazdı. (Sennett, 2009: 75)

Bu açıdan bakıldığında özellikle Orta Çağ'da zanaat ve sanatın birbirinden ayrı olgular olmadığı, aksine birbiri ile iç içe oldukları düşünülebilir. Çünkü Sennett bir zanaatkar ustasının tavrını, yöntemini ve becerilerini bir sanatçının atölyedeki pozisyonundan ayırmaz. Ona göre sanatçı; “'Yalnız Usta"1dır;

Sanatçı kendi çalıșması için özgünlük arayışındadır; özgünlük ise tek başına olan, yalnız bireylerin karakteristiğidir. Aslında pek az Rönesans sanatçısı tecrit halinde çalışmıştır. Zanaat atölyesi sanatçının stüdyosu olarak devam etmiştir, burada da asistanlar ve çıraklar yer almıştı; ancak bu stüdyonun ustaları aslında burada yapılan işin özgünlüğü hakkında yeni bir değer ortaya koymuşlardır. (Sennett,2009: 91-92)

Dolayısıyla sanatta özgünlük, bireysel tavır ve özerklik Rönesans ile birlikte sanatçı kimliğinin de ortaya çıkması ile ilintilidir. Bu özgün tavır Orta Çağ zanaatkarına göre, sanatçıya özel ve özerk bir alan açar, bu alan sanatçının kişiliği ile harmanlanır ve onun iç-dünyasının nesnel gerçekliğine dönüşür.

Tanımı kavramsallaştırmak ve derinlikli inceleyebilmek için, öncelikle atölyenin sanatçı açısından bağlayıcı noktalarını tespit etmek gerekmektedir Çünkü atölye; hem malzeme hem de teknik açıdan sanatçı için bir depo ve motivasyon alanı olmanın ötesinde, siyaseten de kendi kimliğini, karakterini taşıyan, içsel yaşantısını oluşturduğu manevi bir alan özelliğini barındırmakta, sanatçının döneminin tüm özelliklerine de ışık tutmaktadır. Bir sanatçının atölyesini ziyaret etmek, aynı zamanda, sanatçının iç dünyasında bir tür yolculuğa çıkmak gibidir. Bu bağlamda sanatçı için atölyeler gündelik hayat, çalışma, iş, bilgi, sır, laboratuvar, ütopya, galeri vb. birçok rolü beraberinde barındırır.

' “Yalnz Usta”, Richard Sennett’nin Zanaatkar kitabında, Ortaçağdan, Ränesans'a gecis sürecinde özgünlüğünü̈ kazanan usta için kullandığı bir terimdir.
Rönesans'tan 20.yy.'a kadar atölye; sanatçıların birer "Yalnız Usta" olarak yüksek bir zanaat becerisi üzerinden özgün bir tavır aldıkları yer olarak tanımlanabilir. Sennett bu durumu şöyle açılklar;

Rönesans stüdyosu her şeyden önce, ustanın ayırt edici becerileri sayesinde ayakta kalabilmişti; önemli olan, mümkün olduğu kadar fazla resim üretmek değil, onun resimlerini ya da onun tarzındaki resimleri üretebilmekti. Özgünlük, stüdyodaki yüz yüze ilişkilere özel bir önem katıyordu. Kuyumcuların altın analizlerinden fark olarak ressamın yardımcıları kendi ustalarının yanında fiziksel olarak bulunmak zorundaydılar; özgünlüğü, alıp da çantanıza koyabileceğiniz bir kural kitabına yazamazsınız. (Sennett, 2009: 96)

Bu atölyeler aynı zamanda 13.yy'da, kamusal meydanlara, kiliselere vb. mekanlara uygun yapılacak olan uygulamalar için bir araya gelen ekiplerin ortak olarak çalıştıkları, usta - çırak ilişkisinin üst düzeyde olduğu bir çeşit okul görevi görürdü. Ustasının sır - beceri gibi özellikleri, onun kuşaklar arası rol modeli olmasını sağlardı. Ustalık fikri o kadar güçlüydü ki; Sennett'nin "Ustanın bireyselliğinin ve farklılı̆ının hüküm sürdüğü bir atölyede, dile getirilemeyen bilgi de hüküm sürüyor demektir." (Sennett,2009:107) sözü, bir usta olarak sanatçının isminin atölye ile özdeşleștiğini göstermektedir (Örneğin; Leonardo Da Vinci Atölyesi gibi). Bu Atölye - Okul geleneğ 18.yy. ve 19.yy. sanat akademilerinden, 20.yy'ın ikinci yarısına kadar uzanan birçok sanat okulunda görülebilir.

20.yy.'ın başlarında sanatta Natüralist etkinin azalmasını İzlenimcilik, Dışavurumculuk, Kübizm, Gelecekçilik gibi akımlar izledi. Her bir akım özgünlük ve özerklik fikrini daha da fazla kavramsallaştırıyor ve yeni ifade olanakları öneriyordu. Bu dönemin sanatçıları Rönesans sanatçılarının, kilise ve saray ressamlarının aksine, Paris gibi büyük kentlerin dar sokaklarında ufak daireleri atölyelere çeviriyor ve buralarda yalnız çalışarak üretiyorlardı. Bu noktada 20.yy. ile beraber kent olgusunun da sanatta önemli ve belirleyici bir dinamik olarak karşımıza çıktığını düşünebiliriz.

Kenti 'bir kültürel mekan' olarak tanımladığınızda modernizmin sınırları içine giriyoruz; çünkü böylelikle kentin öteki özelliklerinin yanı sıra kültür üreten bir mekan olduğunu önsel olarak kabul ediyoruz. Bununla birlikte bir nokta açıktadır: Acaba, kentin oluşumu dediğimiz, hiç bitmeyen karmaşık sürecin kendisi mi kültüre bir üretimdir, yoksa kent, yarattığı koşullar, çizdiği sınırlar ve koyduğu kurallarla yen bir kültürün üretimine katkıda mı bulunmaktadır? Bir başka deyişle, kentin kendisi üretilen / üretilmiş bir kültür müdür? Yoksa bir kültür üretiminin alt yapısı mıdır? Eğer modernizmin olgularılla bakarak söylemek gerekirse, kent kültürel üretimi örgütleyen bir mekandır. (Kahraman, 2005: 229-230) 
İspanyol sanatçı Pablo Picasso'nun biyografisinde, 1938'e kadar, Paris'te farklı birçok daireyi hem ev, hem de atölye olarak kullandığını görebiliriz (Montmartre Ravignon Sokak 13 numaralı daire, 1910'da Clichy Bulvarı, tekrar Montmarte, Montparnasse, Raspail bulvarı, Schoelcher Sokağı, Montrouge bölgesi ve 1918'de La Boetie sokağı) $)^{2}$. Sadece Paris'in Montmartre bölgesinde, Henri Matisse, George Braque, Toulouse Lautrec, Andre Derain, Amedeo Modigliani, Maurice de Vlaminck, Constantin Brancusi vb. birçok sanatçının da eş zamanlı olarak hem yaşayıp, hem de zaman zaman kapı komşusu oldukları atölyeler açtıklarını biliyoruz. Bu bağlamda atölyeyi, hem sanatçılar arası bir diyalog alanı, hem de kentatölye etkileşimi açısından hayatın içinde yer alan önemli bir dinamik olarak görebilir, sanatta bir biri ardına yaşanan yenilikçi akımların tohumlarının bu atölyelerde atıldığını düşünebiliriz. Bu dönemde sanatçılar her ne kadar yoğun bir etkileşim ve arkadaşık ağı içerisinde olsalar da, bir çoğu modern hayatın yalıızlığı ile de yüzleșmek zorunda kalmıs, yaşanan dünya savaşları ise hem savaş yaşayan toplumun travmasına ortak olmayı, hem de yoksullukla mücadele etmeyi gerektirmiştir.

20.yy.'ın ikinci yarısında, Avrupa'daki savaştan Amerika'ya göç eden sanatçılar yeni izleyici profili ve kurumlarıly yeni bir sanat ortamı oluşturabilmişlerdir.Zamanlabirç̧okyenilikçisanatakımıburada filizlenmeye başlamış, sanatın öncü tavrı ve ruhu, yeni sanat hareketleri üzerinden tekrar vücut bulmaya başlamıştır; Pop-art, Amerikan Dışavurumculuğu, Op-art, Kinetik-art, Minimalizm gibi birçok yeni akım ortaya çıkmaya başlamış, kavramsal sanatın temelleri atılmıştı. Atölye kavramı da, sanatın yeni coğrafyasındaki sınırları ve koşullarına bağlı olarak farkı fiziksel pozisyonlar almıştır. Örneğin Fransız Sanatçı Marcel Duchamp'ın 'Hazır nesne' kavramı ve yeni sanat üretme stratejileri ile atölyenin mekansal zorunluluklarının yavaş yavaş ortadan kalktığı ve sanatçının sanat üretme tercihlerine göre, atölye fikrinin de başkalaştığı görülür. Amerika' da 60'lı yıllardan sonra hem üretim pratikleri açısından, hem de çağın koşulları bakımından atölyenin bir takım fiziksel zorunlulukları, açıç̧a değişim göstermeye başlamış; elektrikle aydınlatma, elektronik vinçler, baskı makineleri ve teknikleri gibi yenilikler üretime katılmıştır. Andy Warhol, Jean-Michel Basquiat gibi sanatçılar Paris'in Montmartre bölgesinde yaşayan sanatçıların aksine, atölye olarak eski fabrikaları, terk edilmis depoları, endüstriyel çatı katlarını vb. alanları tercih etmişlerdir.

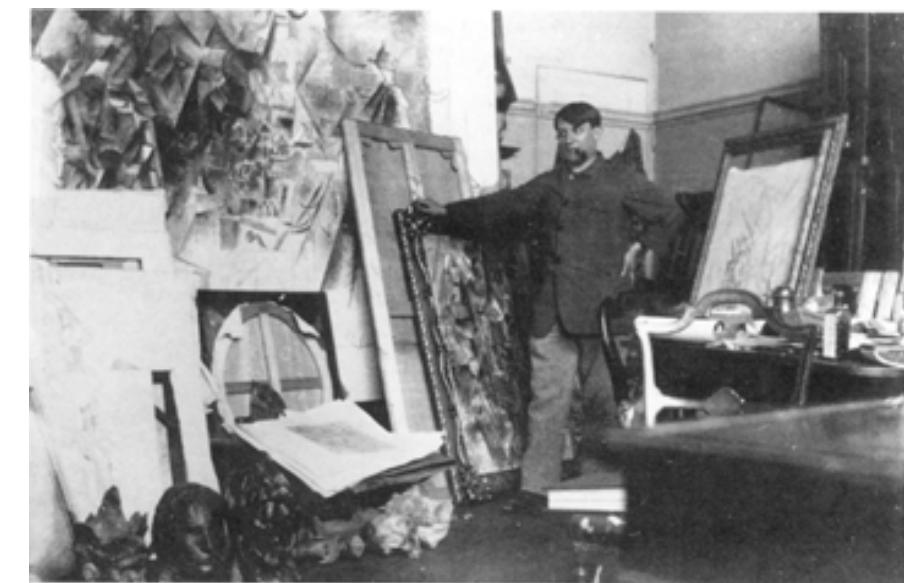

Görsel I. Pablo Picasso, Clichy Bulvarındaki Atölyesi

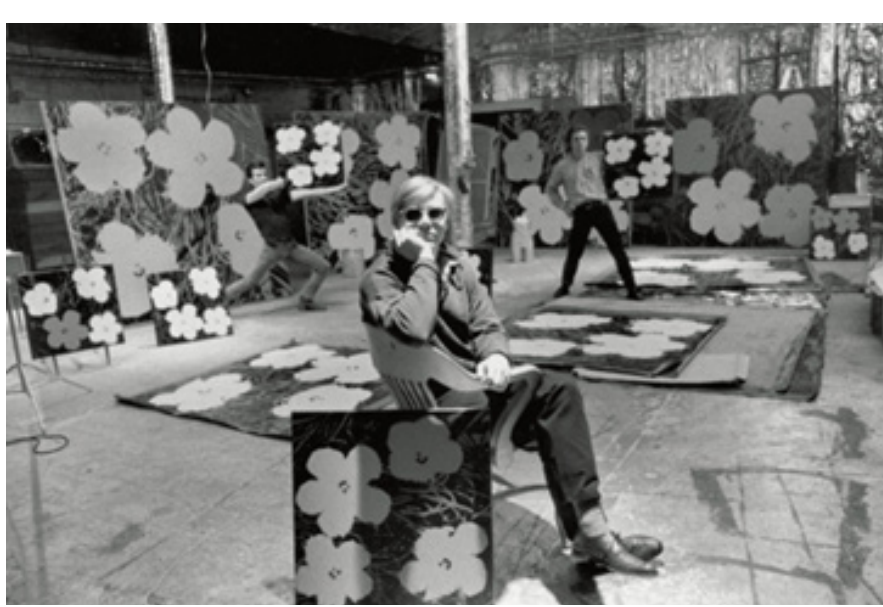

Görsel 2. Andy Warhol'un Fabrika İsmini Verdiği Atölyesi

Batı dünyasında 20.yy'ın son çeyreği ve 21.yy.'ın ilk yıllarını, bireysel özgürlüklerin geliștiği, savaş karşıtlığının yaygınlaştığı, ekonomik refahın yükseldiği, tüketime dayalı para politikalarının küresel çapta etkili olduğu bir dönem olarak özetleyebiliriz. Kuşkusuz bu özellikler 21.yy sanatının yapısını belirleyen temel yapı taşları olarak görülmektedir. 2012 yılında Thames \& Hudson Yayınevi, sanatçı atölyeleri üzerine, orijinal adıyla 'Sanctuary', Türkçesi 'Tapınak' olarak çevirebileceğimiz bir kitap yayınladı ${ }^{3}$. Bu kitapta, Londra'da yaşayan ünlü sanatçılara ve kariyerinin başında ama yükselmekte olan birçok sanatçının atölyesine yer verdi. Büyük bir

${ }^{3}$ Amirsadeghi, H. (2012). Sanctuary. Thames \& Hudson yayınevi tarafindan çıarılan, Ingiltere'de yaşayan sanatçıların atölyeleri hakkında hazırlanmış kitap.
${ }^{2}$ Gertrude Stein'in (1995) Picasso adlı kitabında, Picasso'nun farklı yllarda Paris'te yaşadığı ev/atölye adreslerinden bahsedilmektedir. 
titizlikle hazırlanan kitapta; Frank Auerbach, Ron Arad, Fiona Banner, Peter Blake, Jake and Dinos Chapman, Martin Creed, Tracey Emin, Gilbert \& George, Gavin Turk, Rachel Whiteread gibi günümüz sanat dünyasının önemli aktörlerinin atölyelerinden görselleri görebiliyor, çalışma ortamları ve atölye fikri üzerine düşüncelerini de içeren metinler bulabiliyorsunuz.

Bu atölyelerin, 20.yy.'daki sanatçı atölyeleri ile arasındaki temel farklar nedir? Bu sorunun yanıtını her iki atölye biçiminin karşılaştırmalı olarak incelenmesi ile bulabilir, dönemsel farklııkların atölye üzerinden tartışılmasına olanak sağlayabiliriz.

Bu noktada, Modern heykelin en önemli sanatçılarından biri olarak kabul edilen İsviçre'li Alberto Giacometti'nin atölyesi ile, günümüz sanatının en popüler sanatçılarından biri olarak görülen Japon Ressam Takashi Murakami'nin atölyelerini iki farklı kaynak üzerinden tartışmanın doğru olduğunu düşünülebiliriz.

Fransız düşünür Jean Genet, 1954 yılında Alberto Giacometti'nin atölyesine yaptığı ziyarette Giacometti'nin sanatsal süreci üzerine çarpıcı notlar düşer ve atölyesi üzerine şu notu kaleme alır:

Zemin kattaki bu atölye, yıkıldı yıkılacak zaten. Atölye çürük ahşaptan, gri tozdan heykeller alçıdan ve üzerlerinde ipler, üstüpüler, bazen bir parça çelik tel görünüyor griye boyanmış tuvaller, boyacı dükkanındaki rahatlarını çoktan yitirmişler; herşey lekeli, herşey ıskartada, herşey eğreti, yıkılıvericek, herşey dağılmak üzere, askıda, sallantıda: Ne var ki bütün bunlar, sanki mutlak bir gerçeklik içinde yakalanmış gibi. Atölyeden sokağa çıtığımda, işte asıl o zaman, etrafımda hiçbir şey gerçek değil artık. Söylesem mi acaba? Bu atölyede, bu adam usulca ölüyor, tükeniyor, ve gözümün önünde, başkalaşıma uğrayarak tanrıçalara dönüşüyor. (Genet, 1990: 71)

Genet'nin Giacometti üzerine bu değerlendirmesinin, zamanın koşullarında çoktan ününü kazanmış bir sanatçı için, bugününün koşullarından bakıldığında, çok karamsar olduğu düşünülebilir. Fakat Genet, Giacometti'nin işlerinde yer alan yalnızlık ve tekinsizlik durumunu, çağın önemli bir eleștirisi olarak değerlendirir, sanatçının atölyesinin fiziksel koşullarını, işlerindeki öğeler ile birbirini tamamlar nitelikte olduğunu vurgulayarak atölyedeki ortamın sokaktaki gerçeklikten daha gerçek olduğunu hisseder, hissettirir.

6 Temmuz 2007 tarihinde Kanada'lı Sosyolog Sarah Thornton'un Takashi Murakami Atölyesine yaptığı ziyarete ilişkin notlarını incelediğimizde ise;

Orada, bir asansöre binip atölyeye çıktık. Kapılar açıldığında karşımıza paslanmaz çelik ve camdan bir kapı çıktı, orada parmak izlerimizin kontrol edilmesi ve dört basamaklı bir PIN kodu girmemiz gerekiyordu. Eşikten geçtikten sonra, beyaz çıplak duvarlar ve zımparalanmıs parke zemin başlarda bir galerinin arka odasıymış hissini yarattı ama yakından yüksek güvenlikli bir dijital tasarım laboratuvarı olduğu anlaşılıyordu. İkinci katta iki toplantı odası ve iki açık ofis alanı vardı. Üçüncü kat mimari olarak ikinci kata çok benziyordu ama burası esas yaratıcı çalışmaların yapıldığı yerdi...

Murakami'nin çalışma ünitesi olan beş metre uzunluğundaki masa büyük bir salonun ortasındaydı; masanın çevresinde dört tasarımcı ve beş animasyoncudan oluşan ekibi, sırtları Murakami'ye dönük olarak oturuyorlardı ve bakışlarını beyaz kenarlı yirmi inç boyundaki ekranlarına sabitlemişlerdi. Murakami'nin masasının ortasında bir Mac dizüstü, onun etrafında boş CD'ler, sanat dergileri ve müzayede katalogları, içi boş kağıt kahve bardakları ve bir kutu mini-KitKat çikolata vardı. Salonun sonundaki tezgahta, Tokyo, New York ve Los Angeles zamanlarını gösteren üç saat vardı. (Thornton, 2012: 196)

Görüldüğü üzere, Murakami'nin atölyesi, Giacometti'nin atölyesinin tam aksine çok steril, teknolojik unsurların sonuna kadar kullanıııı̆ı, kalabalık bir ekibin yer aldığı bir plaza ofisi görüntüsüne sahiptir. Ote yandan Murakami tek bir atölye değil, çoklu atölye sistemi kullanan bir sanatçıdır: Hem Japonya'da, hem de New York'ta olmak üzere, üretim amaçl kullandığı farklı atölyelere sahiptir. Bu açıdan bakıldığında Giacometti'ye oranla, Murakami'nin atölyesinde hissettiğimiz duygular, daha mesafeli ve soğuktur. Giacometti'nin atölyesinden duyduğumuz o öznel romantik hazzı, Murakami'nin atölyesinden alamayız. Murakami'nin atölyesi, tüketime dönük bir marka halini almış, şirketleşmiştir. Bu bağlamda Sarah Thornton'un gözlemleri son derece çarpıcıdır;

Murakami, etkisini maksimuma çıkarmak ve bütün ilgi alanlarının peşinden gidebilmek için Kaikai Kiki Ltd. Adında bir şirket kurmuş; Tokyo ve New York'un içinde ve yakınında doksan çalışanı bulunuyor. Sanat simsarları şirketin "çılgın" bir yelpazede faaliyet gösterdiğini söylüyorlar. Bu şirkette sanat üretiliyor. Satılabilecek ürünler tasarlanıyor. Murakami'den başka yedi Japon sanatçı için menajerlik, ajan ve prodüksiyon hizmetleri veriliyor. Ayrıca şirket, Geisai başıılı bir sanat fuarı/ festivali düzenliyor ve moda, televizyon ve müzik şirketlerine milyonlarca dolarlık freelance iş yapıyor. (Thornton, 2012: 187)

Giacometti ise, Murakami'nin aksine yalın, mütevazi bir ev/atölye yaşantısına sahiptir. Genet, Giacometti Ev/Atölyesi üzerine şöyle devam eder;

Oda, Annett'le kendininki, kırmızı taştan bir yer döşemesiyle süslü. Eskiden yer, basık toprakmış. Odanın içine yağmur yağarmış. Yer döşemesine içi sızlayarak razı olmuş. Döşemelerin en güzeli, ama aynı zamanda en gösterişsizi. Bu atölyeyle 
odadan başkaca yer istemediğini söylüyor bana. Mümkün olsa, gönlü, daha da basitinde. (Genet, 1990: 45)

Giacometti'nin mütevaziliğinin aksine, Murakami'nin tüm sanatsal pratiğini bir holding patronu gibi yönetiyor olması, 20.yy ile 21.yy sanatçılarının arasındaki belki de en temel farklılığın göstergesidir. Sanatçının kendi sanatına olan sıcak teması, Murakami de fabrikasyon bir üretime dönüşmüş, pazarlama, satış, reklam gibi konular atölyenin bağlamına dahil edilmiştir. Bu her iki örnekten anlaşılabileceği gibi atölye algısı, sanatçının yaratma süreci ile olan bağlantısı, taşıdığı anlam, kullanım özellikleri vb. tüm dinamikleri dönemsel farklılıkların ışığında başkalaşmıştır.

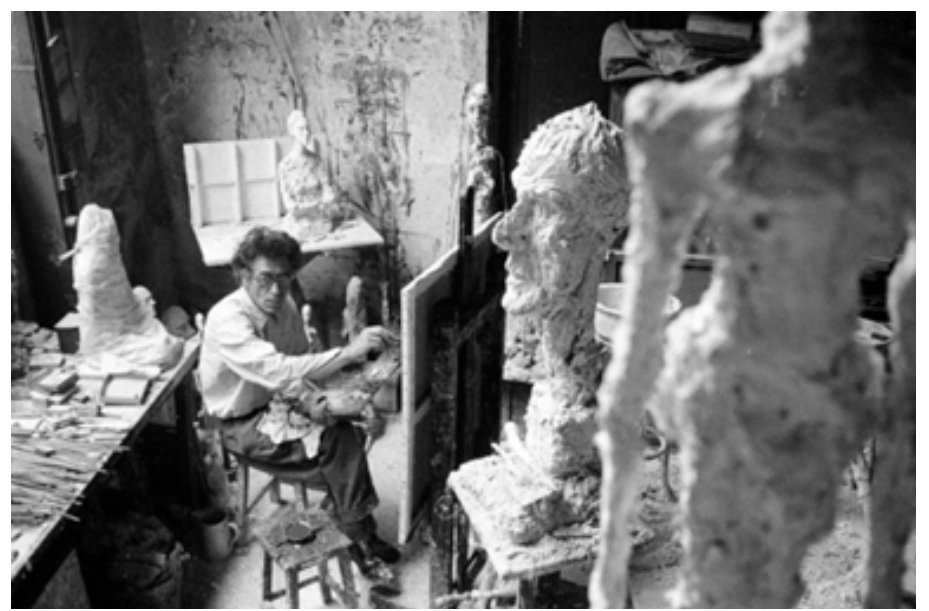

Görsel 3. Alberto Giacometti Atölyesi

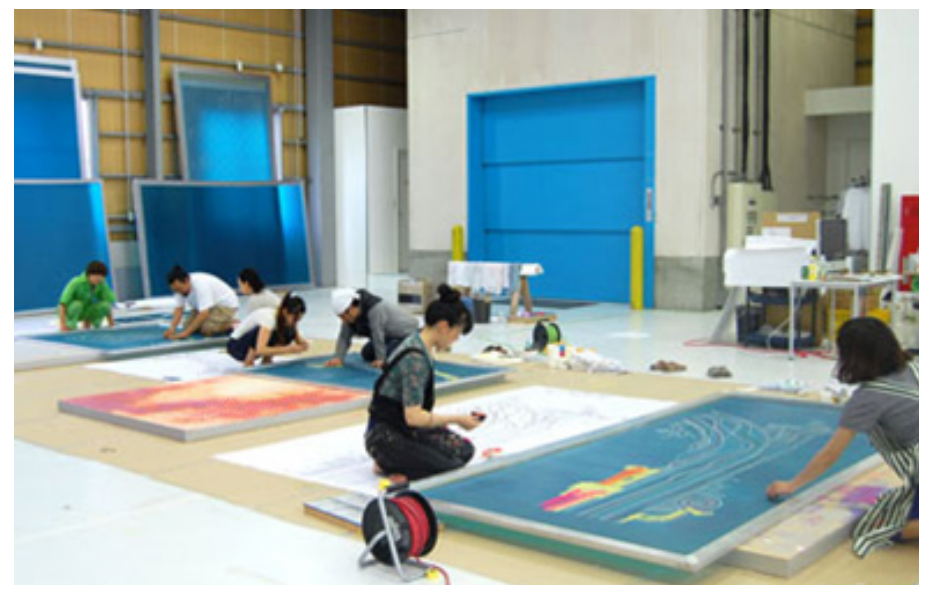

Görsel 4. Takashi Murakami Atölyesi
Sanat sadece atölyede mi üretilir? Ya da atölyeye alternatif alanlar nelerdir? Bu soruların yanıtlarını, sanatın pek çok alanında radikal değişimlerin yaşandığı 20.yy.'ın ikinci yarısında bulabiliriz.

\section{Derive Kuramı Ve Alternatif Atölye Modelleri}

Derive, Sitüasyonistlerin öne sürdüğü gibi, kentin "akılcı, işlevsel, yönlendirici düzenine karşı arzulara, deneyci ve özgür davranışlara, toplumsal hareketlere, oyunsu yaratıcılığa, kısaca sanata ve şiire teslim olmasını ifade eder" (Artun, 2010: 313).

Bu bağlamda, sanatsal üretimin sokağa çıktığı, kapı dışı sanatının kendini göstermeye başladığı ve buna bağ ı alternatif yöntemlerin de şekillendiğini görürüz: "Bir Derive sırasında bir ya da birçok kişi belli bir süreliğine alışıldık hareket ve eylem niyetlerini, ilişkilerini, işlerini ve boş zaman etkinliklerini bırakır ve kendilerini sahanın cazibelerine ve sahada bulacakları karşılaşmaların tesadüfüne bırakırlar." (Artun, 2010: 314)

Birtür çağrı niteliği de taşıyan Derive kuramı ile adına "Saha" diyebileceğimiz kent ve sokaklar, atölyenin dışında bir üretim mecrası olarak algılanmaya başlanmıştır.

Terminolojik olarak "Saha", jeoloji, jeofizik, antropoloji ve arkeoloji gibi çok önemli alanlarda bir çalışma alanı ve yöntemi olarak karşımıza çıkmaktadır. Sanatsal bağlamda ise, "Derive" kavramı üzerinden "Saha"yı özellikle kent olgusu ile ilişkili deneysel, rastlantısal bir yaratıcı alan olarak değerlendirebiliriz.

20.yy. başlarında, bir antropolog gibi sahayı kullandığını düşündüğümüz Gauguin'in Afrika coğrafyasında gerçekleştirdiği seyahatler, dönemin koşul ve şartlarında bir saha çalışması olarak adlandırılmasa da, yaptığı araştırmaların antropolojik incelemeleri içermesi nedeniyle, günümüzde bir saha araştırması olarak değerlendirilebilir. Böylece, sanatta "ilkelcilik" akımının da bu saha araştırmaları ile yakından ilişkisi olduğunu düşünürsek, "Saha"yı hem Gauguin vb. sanatçıların ele aldığı gibi bir araştırma alanı, hem de Sitüasyonistlerin "Derive" kuramı ile bir uygulama alanı olarak iki farklı şekilde ele alabiliriz. Öncelikle kent üzerinden bir uygulama alanı tanımlarsak, ilk olarak "Grafiti" yani sokak sanatı akla gelir: 1970'lerin başında Amerika'da görülmeye başlanan grafiti, sanatçıların kimliklerini gizleyerek belli "tag"lar üzerinden sokakta, kamusal alanda gerçekleştirdikleri duvar resimleridir. Bu hareket kısa sürede Hip-hop vb. alternatif kültürel hareketlerle Amerika'dan Avrupa'ya oradan da birçok coğrafyaya yayılan ve günümüzde de hala yoğun olarak kullanılan bir 
sanatsal ifade aracı olmuştur. Özellikle 2000'li yıllardan sonra grafiti sanatı o kadar kabul gördü ki, sanatçıların artık kimliklerini gizlemek zorunda kalmadıkları, galeriler, sanat merkezleri vb. kurumlarla da iş birliği yaptıkları geniş pazar payına sahip bir alan haline geldi. Grafitinin dışında, özellikle 60'lı yılların başında, sanatta alternatif hareketlerin hızla yükseldiği bir dönemde, saha uygulamaları kapsamında değerlendirebileceğimiz atölyeye alternatif modellerin de ortaya atıldığını görebilmekteyiz. Örneğin; Eylemler, Arazi Sanatı, Performans vb. sanat hareketleri kapsamında değerlendirebileceğimiz örneklere bakıldığında: Fransız Sanatçı Daniel Buren'in kamusal alana çıkarak Los Angeles'da otobüs banklarına yaptığı işler, yine İsviçre'de Billboard'lar üzerinde gerçekleştirdiği çalışmalar ya da Robert Smithson'ın arazi işleri, Yves Klein'in tuval üzerine çıplak modeller kullanarak gerçekleştirdiği performanslar vb. Bu işlerin hepsi, alternatif atölye modelleri olarak değerlendirilmektedir. Bu üretim biçimleri bilinçli olarak doğrudan saha çalışması hedefi ile geliştirilmemiştir: 60'lı yıllarda sanatın çok daha radikal değişimler ve açılımlar gerçekleştirmek üzere alternatif stratejiler belirlediğini gözlemleriz: Ana hedefler arasında; sanatı bir meta olarak reddetmek, eğlence olarak reddetmek, sanatın yapısını sorgulamak, sanat bağlamını çözümlemek, yeni bir kültür üretmek, sanatsal disiplinler arası sınırları ortadan kaldırmak vb. amaçlar sayılabilir. Bu radikal hedefler bir o kadar radikal yöntemleri, metotları da beraberinde ortaya çıkarmıştır.

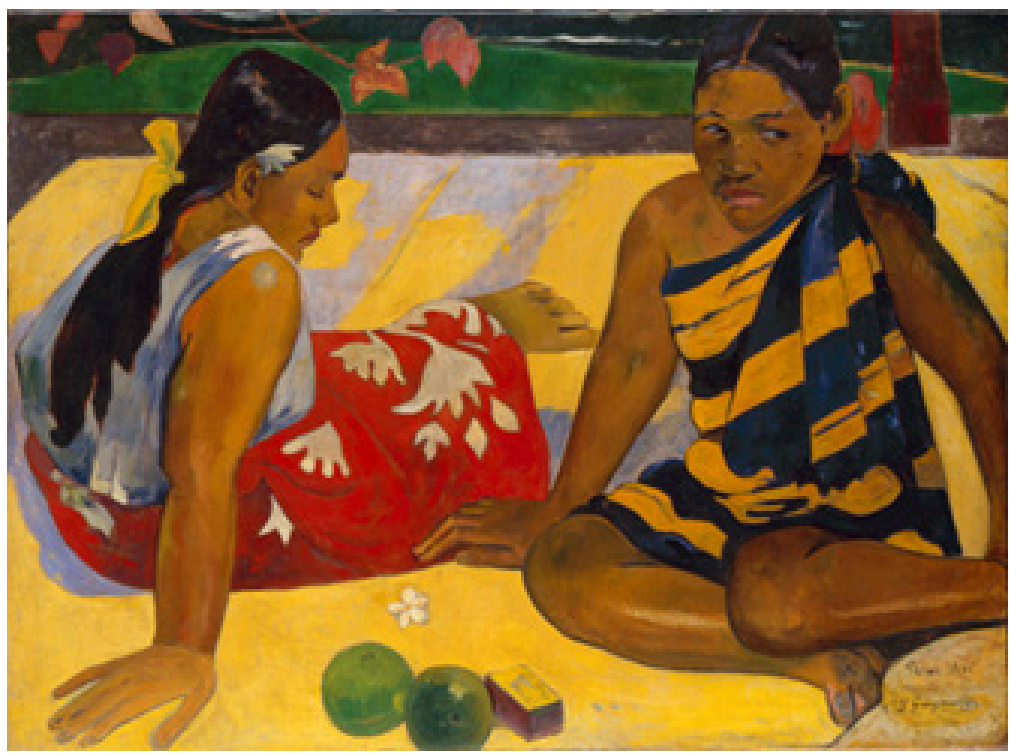

Görsel 5. Paul Gauguin, Parau api, I892, tuvale yağlı boya

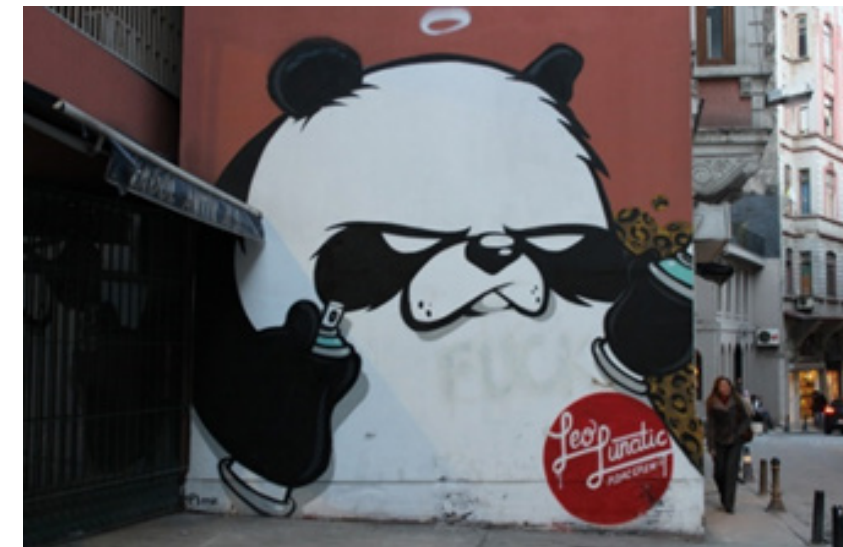

Görsel 6. Leo Lunatic Etiketli Graffiti, İstanbul

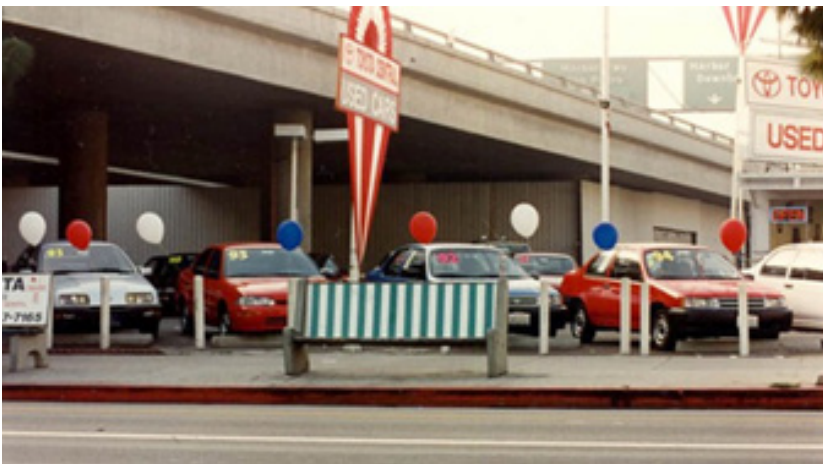

Görsel 7. Daniel Buren, Los Angeles Otobüs Bankları, 1970

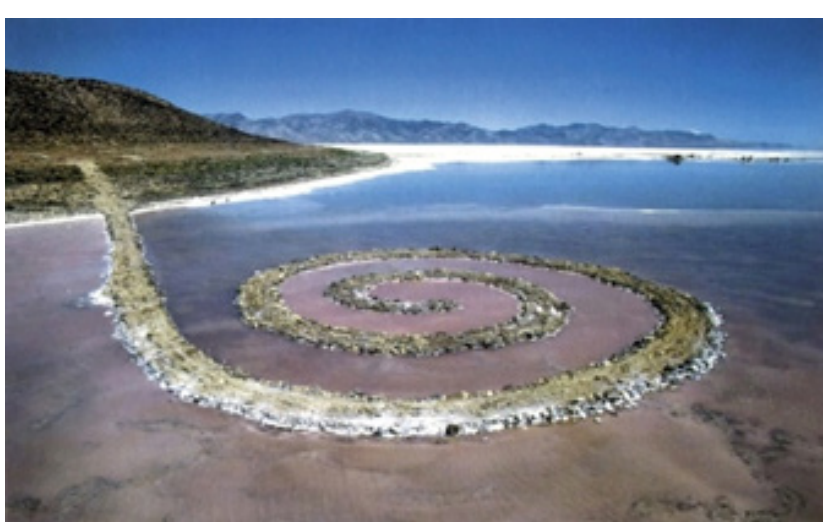

Görsel 8. Robert Smithson, Spiral Jetty, Utah, 1970 
Üretim alanı açısından saha'nın günümüzdeki koşul ve pozisyonuna gelmeden önce, antropolojik açıdan saha ile sanatın sınırlarının kesiştiği örneklere bakabiliriz:

Venezüela'lı sanatçı Fernando Calzedilla ve Venezüella'da yaşayan Küba doğumlu sanatçı Abdel Hernandez'in beraber ürettikleri ve bu üretim sürecinde Rice Üniversitesi'nden Antropolog George Marcus'un yardımıyla araştırma sürecini yürüttükleri "Market from Here" isimli yerleştirme, belki de antropoloji ve sanat arasındaki sınırların tamamen bulanıklaştığı ilk örneklerden biri. Calzedilla ve Hernandez "Market from Here" adlı çalışmada hem kendi yaşadıkları çevreden alışkın oldukları hem de çeşitli şehirlerde yaptıkları araştırma ve gözlemler sonucunda damıttıklarıyla bir Pazar yeri yaratıyorlar. Bu Pazar yerinde izleyici sadece Pazar yeri imgesiyle değil, baharat ve yiyeceklerin kokularılla, satın aldıkları objelerle, hatta kimi zaman pazarcının kendisiyle karşılaşıyorlar. (Özata, 2016: 33)

Bu örnekten de anlaşlabileceği gibi "Saha Araştırması", antropoloji ile sanatın iç-içe geçtiği sanat olgusunda, alternatif atölye modeli olarak düşünülebilir. Bu bağlamda, Çin'li sanatçı Ai Weiwei'in uzun bir süredir Suriye i̇ç Savaşı nedeniyle yaşanan, tarihteki en büyük mülteci sorunlarından biri üzerine gerçekleştirdiği saha çalışması dikkate değerdir. Ai Weiwei, uzun süre Midilli adasında mültecilerle beraber yaşamış, onların göç süreçlerine birebir tanıklık etmiş, hatta atölyesini buraya taşıyarak sahayı; hem antropolojik bir araştırma alanı, hem de uygulama alanı olarak değerlendirerek saha çalışmasının her iki özelliğini de bir arada kullanmıştır. Ai Weiwei, adada kaldığı sürede edindiği deneyimler üzerinden bir seri iş üreterek Amerika'da ve Avrupa'da birçok büyük çaplı sergi ve proje de gerçekleştirmiştir. Ai Weiwei saha çalışmasına rastlantı olarak başladığı, konunun içine girdikçe konunun onu daha da çok içine aldığını belirtmiş ve son dönem tüm işlerini de bu konu üzerine odaklamıştır. Çalışmalarını Lübnan'dan Midilli'ye birçok farklı durakta araştırma yaparak gerçekleştiren sanatçı, konuya ilişkin bir de belgesel hazırlamıştır.

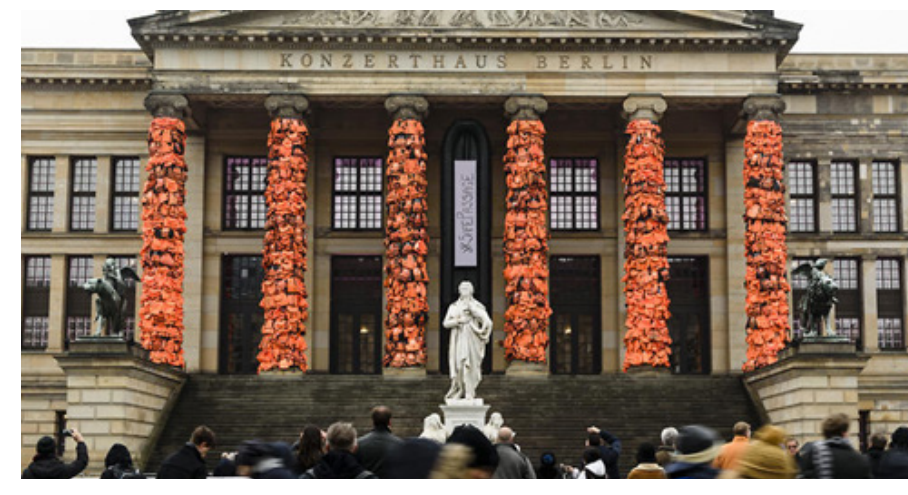

Görsel 9. Ai Weiwei, Midilli Adasından toplanmış /4.000 Can Yeleği ile gerçekleştirilen Yerleştirme, 2016,
Günümüzde, bazıözellikleriylesahaçalışmasıolarakdatanımlayabileceğimiz başka alternatif sanat üretme platformları da bulunmaktadır: Sanatçı konaklama programları, çalıştaylar, uygulamalı sanat sempozyumları ve küratör bazlı projeler üzerinden bu durumu örneklemek mümkündür. İster kurumsal bir programın kapsamında olsun, ister sanatçının bağımsız iradesiyle bir göçebe olarak çalışma niyetiyle ilgili olsun, hepsinin ortak özelliği; bulundukları mekanın, coğrafyanın vb. olanakları ölçüsünde çalışma fikrini benimsemek ve mekan olarak sabit bir atölye fikrinin tüm teknik ve manevi özelliklerine uzak mesafeli bir tutumu, bilinçli olarak pratiklerinde tercih etmeleri olarak özetlenebilir. Örneğin, Ayşe Erkmen'in Berlin DAAD Galeri'deki işi üzerine söyledikleri, bu yöntemi benimsediğini göstermesi açısından dikkate değerdir:

Mekanla çalışınca, mekana yeni bir şey taşımadan, dışarıdan bir şey getirmeden, sadece mekanda olanlarla yetinmek hoşuma gidiyor. Odaların kendine özgü ayrıntıları, aykırılıkları,... her mekanın kendinde yapabilecekleri var. Örneğin Berlin'de bulunan DAAD Galeri'sinde gerçekleştirdiğim 'Ev' adlı sergi de tek yaptığım şey ışıkları aşağıya indirebilmek için ek bir teknik çalışma bile yapmadım. Işıkların üzerindeki kıvrılmış teller zaten aşağıya indirebilmek için yeterliydi, sanki bekliyordu. (Meschede, 2008: 96).

Ayşe Erkmen'in bu pratiğinden de anlaşılabileceği üzere, atölye fikri bu çalışmada tamamen ötelenmiş, hatta reddedilmiştir. Bu tür sanatçılık deneyimi, kendi çağdaşlarından kabul edebileceğimiz Takashi Murakami, Anish Kapoor, Damien Hirst, Jeff Koons vb. sanatçıların dev fabrikaları, ulus aşırı çoklu stüdyo modellerine alternatif bir yöntem olarak okunabilir. Bu yöntem üslup açısından sanatçıya bir özgürlük alanı tanır, tesadüf, rastlantı gibi faktörler büyük önem kazanır, üslup yerini anlatıya bırakır. Mekan, mimari büyük bir ilişkisellik kazanır çünkü artık, imge atölye sınırları içerisinde keşfedilmeyi bırakmışıır.

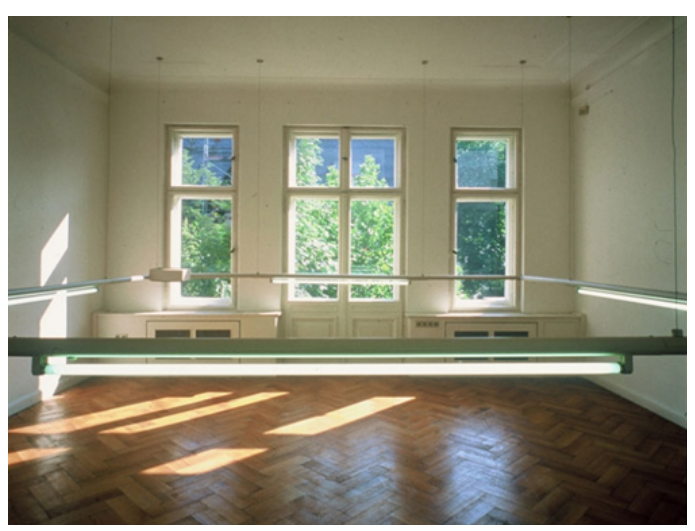

Görsel 10. Ayşe Erkmen, Ev, 1993, DAAD Galeri, Berlin 


\section{Sonuç}

Günümüz sanatında büyük prodüksiyonların yapıldığı atölyelerin, içinde çok sayıda asistanın yer aldığı fabrika benzeri alanlara dönüşmüş olduğu düşünülecek olursa atölye olgusu, sanatta hala geçerliliğini koruyan önemli bir dinamik ve en yaygın tercih edilen çalışma yöntemi olarak gözükmektedir. Ama sanat tarihine baktığımızda, gelişen sürecin tahlil ve analizleri, aynı zamanda örnekleri, sanatsal pratik açısından çalışma yönteminin salt atölye üzerinden olmadığını bize kanıtlar niteliktedir.

Öyleyse denilebilir ki; Sanata ulaşmanın sınırlarının ve yollarının oldukça genişlediği bir dönemde saha çalışması ya da atölye çalışması arasında bir tercih, ancak sanatçının niyetiyle ilgili olabilir. Önemli olan, her iki olgunun da zaman zaman tematik, zaman zaman da koşullar ve şartlar üzerinden tercih edilebilecek farklılıkları olduğudur. Bu farklılıklar, sanatçılar için her zaman yeni anlatım yöntem ve metotlarını önermekte, günümüzde sanat nedir? hangisidir? sorularını akla getirmekte ve çağdaş sanatın sınırlarını belirlemektedir. 


\section{Kaynakça}

Artun, A. (2010). Sanat Manifestoları. İstanbul: IIletişim Yayınları.

Genet, J. (1990). Giacometti'nin Atölyesi (Çev. H. Yumer). İstanbul: Metis Yayınları.

Kahraman, H.B. (2005). Sanatsal Gerçeklikler, olgular ve öteleri..., Istanbul: Agora Yayınları

Meschede, F. (2008). Ayşe Erkmen uçucu / şimdi (Çev. O. Duman). İstanbul: Yapı Kredi Yayınları.

Özata, L. (2016). “Sanatın Araştırma Sahası”, İstanbul Art News, 33 (I2).

Sennett, R. (2009). Zanaatkar (Çev. M. Pekdemir). İstanbul: Ayrıntı Yayınları.

Stein, G. (1995). Picasso (Çev. K. Özsezgin). İstanbul: Gece Yayınları.

Thornton, S. (20/2). Sanat Dünyasında Yedi Gün (Çev. M. Haydaroğlu). İstanbul: Yapı Kredi Yayınları.

\section{Görsel Kaynakları}

Görsel I. Pablo Picasso, Clichy Bulvarındaki atölyesi. https://americangirlsartclubinparis com/2014/10/03/madame-picasso-in-paris/. Erişim tarihi:10.07.2017

Görsel 2. Andy Warhol'un Fabrika ismini verdiği atölyesi. http://admin.xpatnation.com/ wp-content/uploads/2015/06/Screen-Shot-2015-06-09-at-10.03.24-PM.png. Erişim tarihi: 10.07.2017

Görsel 3. Alberto Giacometti Atölyesi. https://www.ernst-scheidegger-archiv.org/en/ photos-of-artists/alberto-giacometti/?id=447. Erişim tarihi: 10.07.2017

Görsel 4. Takashi Murakami Atölyesi. http://english.kaikaikiki.co.jp/news/list/art_ autumn_in_miyoshi_I/. Erişim tarihi: 10.07.2017

Görsel 5. Paul Gaugain, Parau api, I892, tuvale yağlı boya. http://www. jenniferdeborahwalker.com/blog/gauguin-from-the-exotic-to-the-avant-garde. Erişim tarihi: 10.07.2017

Görsel 6. Leo Lunatic Etiketli Graffiti, Istanbul. http://bigumigu.com/haber/yapi-kredisubelerine-leo-lunatic-ten-graffiti/. Erişim tarihi: 10.07.2017

Görsel 7. Daniel Buren, Los Angeles Otobüs Bankları, 1970. https://blogs.uoregon.edu/ danielburen/posts/. Erişim tarihi: 10.07.2017
Görsel 8. Robert Smithson, Spiral Jetty, Utah, 1970. https://www.khanacademy.org/ humanities/art-1010/minimalism-earthworks/a/smithsons-spiral-jetty. Erişim tarihi: 10.07.2017

Görsel 9. Ai Weiwei, Midilli Adasından toplanmış 14.000 Can Yeleği ile gerçekleştirilen Yerleştirme, 2016, Berlin Konser Salonu. http://www.sbs.com.au/news/ article/2016/02/15/ai-weiwei-covers-berlin-landmark-refugee-life-vests. Erișim tarihi: 10.07.2017

Görsel 10. Ayşe Erkmen, Ev, 1993, DAAD Galeri, Berlin. https://www.yatzer.com/beyondthese-walls-south-london-gallery. Erişim tarihi: 10.07.2017 